\title{
МОЛОЧНАЯ ПРОДУКТИВНОСТЬ ПЕРВОТЕЛОК ЕНИСЕЙСКОГО ТИПА КРАСНО-ПЕСТРОЙ ПОРОДЫ В ЗАВИСИМОСТИ ОТ ЛИНЕЙНОЙ ПРИНАДЛЕЖНОСТИ И ВОЗРАСТА ПЕРВОГО ОТЕЛА
}

A.V. Pellinen, A.I. Golubkov, A.I. Kuznetsov, A.A. Golubkov

\section{MILK PRODUCTIVITY OF THE YENISEI TYPE OF RED-MOTLEY BREED, DEPENDING ON LINEAR ACCESSORIES AND FIRST BREAST AGE}

Пеллинен А.B. - гл. зоотехник-селекционер АO «Солгон», Красноярский край, Ужурский р-н, с. Солгон.

E-mail: alex_sib_24@mail.ru

Голубков А.И. - д-р с.-х. наук, проф., зав. Красноярской лаб. разведения крупного рогатого скота Всероссийского НИИ племенного животноводства, Красноярский край, Емельяновский р-н, п. Солонцы.

E-mail: alex sib 24@mail.ru

Кузнецов $\bar{A}$.И. - д-р с.-х. наук, директор Иркутского НИИ сельского хозяйства, Иркутская обл., п. Пивовариха.

E-mail: kai.2206@mail.ru

Голубков А.А. - науч. сотр. Красноярской лаб. разведения крупного рогатого скота Всероссийского НИИ племенного животноводства, Красноярский край, Емельяновский р-н, п. Солонцы.

E-mail: alex_sib_24@mail.ru

Цель исследования - проведение оценки молочной продуктивности первотелок енисейского типа красно-пестрой породы в зависимости от возраста 1-го отела и линейной принадлежности. Исследования проводились на первотелках, полученных от подбора внутрилинейно: Вис Бек Айдиал (В.Б.А.) × Вис Бек Айдиал, Рефллекшн Соверинг (Р. Сов.) × Рефрлекшн Соверинг, Монтвик Чифотейн (М. Ч.) × Монтвик Чифртейн, Розейфь Ситейшн (Р. Сит.) × Розейф Ситейшн, Силине Трайджун Рокит (С.T.P.) × Силинг Трайджун Рокит, Пабст Говернер (П.Г.) × Пабст Говернер, и первотелок, полученных от межлинейных кроссов: М.Ч. × В.Б.А., М.Ч. × Р. Сов., М.Ч. × Р. Cum., М. Ч. × С.Т.Р., М.Ч. × П.Г., P. Cum. $\times$ В.Б.А., Р. Cum. $\times$ П.Г., Р. Cum. $\times$ М. Ч., P. Cum. $\times$ P. Co8., P. Co8. $\times$ M. 4., P. C08. $\times$
Pellinen A.V. - Chief Livestock SpecialistSelectioner, JSC "Solgon", Krasnoyarsk Region, Uzhur District, V. Solgon.

E-mail: alex_sib_24@mail.ru

Golubkov A.I. - Dr. Agr. Sci., Prof., Head, Krasnoyarsk Laboratory of Cattle Breeding, All-Russia Research and Development Institute of Animal Husbandry, Krasnoyarsk Region, Emelyanovo District, S. Solontsy.

E-mail: alex_sib_24@mail.ru

Kuznetsov A.I. - Dr. Agr. Sci., Prof., Director, Irkutsk Research and Development Institute of Agriculture, Irkutsk Region, S. Pivovarikha.

E-mail: kai.2206@mail.ru

Golubkov A.A. - Staff Scientist, Krasnoyarsk Laboratory of Cattle Breeding, All-Russia Research and Development Institute of Animal Husbandry, Krasnoyarsk Region, Emelyanovo District, S. Solontsy.

E-mail: alex_sib_24@mail.ru

B.Б.А., Р. Сов. × С.Т.Р., в стаде племенного завода АО «Солгон» Ужурского района Красноярского края. Исследования признаков молочной продуктивности первотелок провели в зависимости от линейной принадлежности, полученных от внутрилинейного подбора и от кросса линий - в зависимости от возраста 1-го отела. Первотелки с законченной лактацией, отелившиеся в 2019 г., были разбиты на 4 группь:: 1-я - с отелами в 21-22 мес.; 2-я - в 2324; 3-я - в 25-26; 4-я - в 27 и более месяцев. Основным источ-ником информации служила программа племенного учета «СЕЛЭКС Молочный скот», а также племенные карточки фр. 2мол. Доказана воз-можность увеличения молочной продуктив-ности (удой, выход молочного жира и белка) у коров енисейского типа крас- 
но-пестрой породы в племзаводе $A O$ «Солгон». У первотелок линии М. Чифотейн, полученных от внутрилинейного разведения и осемененных в возрасте 12-13 мес., увеличение составило: по удою - на 3,1-20,5 \%, по выходу молочного жира - на 2,84-19,3\%, по выходу молочного белка - на 0,54-1,48 \%; у первотелок линии М.Ч. × М.Ч., осемененных в возрасте 14-15 мес., отмечено увеличение молочной продуктивности: по молоку - на 0,6-1,2 \%, по выходу молочного жира - на 0,6-1,7 \%, по выходу молочного белка - на 0,5-1,5\%; у первотелок, получен-ных от межлинейного подбора линий М.Ч. × C.T.P., слученных в возрасте 12-13 мес.: по удою - на 10,7-22,9 \%, по выходу молочного жира - на 6,4 $10,6 \%$, по выходу молочного белка - на 10,4 $21,7 \%$.

Ключевые слова: молочная продуктивность, возраст 1-го отела, енисейский тип красно-пестрой породы, линейная принадлежность, первотелки.

The research objective was carrying out the assessment of dairy efficiency of firstcalf heifers of the Yenisei type of red-and-motley breed depending on the age of the 1-st calving and linear accessory. The studies were carried out on the first calf heifers obtained from intra-linear selection: Vis Beck Ideal (V. B. I.) $\times$ Vis Beck Ideal, Reflection Sovereign (R. Sov.) $\times$ Reflection Sovereign, Montic Chieftain (M. Ch.) $\times$ Montic Chieftain, Roseif Sitation (R. Sit.) $\times$ Roseif Sitation, Seeling Trajan Rocket (S. T. R.) $\times$ Seeling Trajan Rocket, Pabst Governor × (P. G.), x Pabst Governor and the first-calf derived from interline crosses M. Ch. $\times$ V. B. I., M.Ch. × R. Sov., M.Ch. $\times$ R. Sit., M. Ch. $\times$ S. T. R., M. Ch. $\times$ P. G., R. Sit. $\times$ V. B. I., R. Sit. $\times$ P. G., R. Sit. $\times$ M. Ch., R. Sit. $\times$ R. Sov., R. Sov. $\times$ M. Ch., R. Sov. $\times$ V. B.I., $R$. Sov. $\times S . T$. R. in the herd of breeding plant JSC "Solgon" Uzhur, district of Krasnoyarsk Region. The researches of signs of dairy efficiency of firstcalf heifers were conducted depending on linear accessory, received from intra linear selection and from cross-country of lines - depending on the age of the 1st calving. The firstcalf heifers with finished lactation which calved in 2019 were divided into 4 groups: the 1st - with calving at 21-22 months; the 2nd - at 23-24; the 3rd - at 25-26; the 4th - at 27 and more months. The program of breeding account "SELEX Dairy cattle", and also breeding cards were the main source of information: $f$. 2milk. The possibility of increasing in dairy efficiency (milk yield, milk fat and protein exit) in cows of the
Yenisei type of red-and-motley breed in breeding farm of JSC 'Solgon' was proved. Firstcalf heifers of the lines $M$. Chieftain, received from intra linear selection and inseminated at the age of 12-13 months, the increase made: in milk yield - for 3.1$20.5 \%$, in milk fat exit - for $2.84-19.3 \%$, in milk protein exit - for 0.54-1.48\%; in firstcalf heifers of the lines M. Ch. $\times$ M. Ch. inseminated at the age of 14-15 months the increase in dairy efficiency was noted: in milk - for 0.6-1.2\%, in milk fat exit - for $0.6-1.7 \%$, in milk protein exit -for 0.5-1.5\%; in the firstcalf heifers received from interlinear selection of lines M. Ch. $\times$ S. T. R., coupled at the age of 12-13 months: in milk yield - for 10.7-22.9 \%, in milk fat exit - for 6.4-10.6\% , in milk protein exit - for 10.4$21.7 \%$

Keywords: milk productivity, age of the 1st calving, Yenisei type of red-and-motley breed, linear affiliation, first-calf heifers.

Введение. Молочная продуктивность коров молочного и молочно-мясного типа продуктивности зависит от паратипических и генотипических фракторов. К генотипическим относятся линейная принадлежность и продуктивные качества родителей. К паратипическим факторам относятся кормление и содержание коров, период лактации, возраст матерей, возраст и живая масса телок при осеменении, возраст и живая масса коров при первом отеле, длительность сервис-периода и межотельного периода.

Вероятной возможностью повышения молочной продуктивности у коров является увеличение их племенной ценности, на которое наряду с генотипом животных большое влияние оказывают и паратипические фракторы: возраст первого тела и удой от первотелок.

В Сибирском регионе енисейский тип краснопестрой породы был выведен методом воспроизводительного скрещивания маток краснопестрой породы и пород молочной продуктивности мирового уровня голштинской и шведской красной (патент № 4804 от 22.06.2009 г.), данный тип занимает в структуре молочных пород Красноярского края 31,5 \%. В связи с этим возможно совершенствование породных и продуктивных качеств енисейского типа краснопестрой породы современными методами с использованием геномной селекции, позволяющей отобрать животных в молодом возрасте, еще до года, сформировать стадо в генетическом отношении наиболее ценное, в этом акту- 
альность, теоретическая и практическая значимость работы.

Цель исследования: проведение оценки молочной продуктивности у первотелок енисейского типа красно-пестрой породы в зависимости от возраста первого отела и линейной принадлежности.

В задачи исследования входило:

- сформировать группы случайных телок в возрасте 12-13, 14-15, 16-17, 18 и более месяцев в зависимости от линейной принадлежности при внутрилинейном подборе и кроссах линий;

- определить у первотелок всех групп молочную продуктивность (удой (в кг) за всю лактацию и за 305 дней лактации, МДЖ и МДБ (в абсолютных и относительных величинах), живую массу (в кг);

- сравнить результаты показателей молочной продуктивности и живой массы всех подконтрольных групп, полученных в результате внутрилинейного подбора и при кроссах линий;

- выявить лучшее сочетание пар при внутрилинейном подборе и кроссах линий и предложить их разведение племзаводу.

Материал и методы Исследования. Исследование проводилось на первотелках енисейского типа красно-пестрой породы в ПЗ АО «Солгон» Ужурского района Красноярского края разного линейного происхождения:

- при внутрилинейном разведении Вис Бек Айдиал (В.Б.А.) × Вис Бек Айдиал, Рефрлекшн
Соверинг (Р.Сов.) × Рефрлекшн Соверинг, Монтвик Чифтейн (М.Ч.) × Монтвик Чифтейн, Розейф Ситейшн (Р.Сит.) × Розейф Ситейшн, Силинг Трайджун Рокит (С.Т.Р.) × Силинг Трайджун Рокит, Пабст Говернер (П.Г.) × Пабст Говернер;

- при кроссах линий М.Ч. × В.Б.А., М.Ч. × Р.Сов., М.Ч. × Р.Сит., М.Ч. × С.Т.Р., М.Ч. × П.Г., Р.Сит. × В.Б.А., Р.Сит. × П.Г., Р.Сит. × М.Ч., Р.Сит. × Р. Сов., Р.Сов. × М. Ч., Р.Сов. × В.Б.А., P.CoB. $\times$ C.T.P.

В опыте участвовали первотелки, полученные от внутрилинейного разведения в количестве 290 голов и полученные от кросса линий в количестве 512 голов отелов: 2-я половина 2018 г. и 1-я половина 2019 г. Все первотелки были разбиты на 4 группы: 1-я - с отелами в 21-22 месяца, 2-я - в 23-24 месяца, 3-я - в 2526 месяцев, 4-я - в 27 и более месяцев, - и 5-я - в среднем по племзаводу. Данные молочной продуктивности первотелок были получены из программы «СЕЛЭКС. Молочный скот», а также племенных карточек ф.. 2-мол.

Для обработки полученных данных применяли общепринятые статистические методы (Меркурьева Е.К. и др., 1990), достоверность показателей оценивали по Стьюденту.

Результаты исследования. В таблице 1 приведены показатели молочной продуктивности первотелок в зависимости от линейной принадлежности.

Таблица 1

\section{Молочная продуктивность первотелок в зависимости от линейной принадлежности}

\begin{tabular}{|c|c|c|c|c|c|c|c|c|}
\hline \multirow{2}{*}{$\begin{array}{c}\text { Принад- } \\
\text { лежность } \\
\text { к линии }\end{array}$} & \multirow{2}{*}{ 突 } & \multirow{2}{*}{$\begin{array}{l}\text { Кол-во } \\
\text { дойных } \\
\text { дней }\end{array}$} & \multirow{2}{*}{$\begin{array}{c}\text { Удой за всю } \\
\text { лактацию, } \\
\text { кг }\end{array}$} & \multirow{2}{*}{$\begin{array}{c}\text { Удой за } \\
305 \text { дней } \\
\text { лактации, } \\
\text { кг }\end{array}$} & \multicolumn{2}{|c|}{ МДЖ } & \multicolumn{2}{|c|}{ МДБ } \\
\hline & & & & & $\%$ & Кг & $\%$ & Кг \\
\hline 1 & 2 & 3 & 4 & 5 & 6 & 7 & 8 & 9 \\
\hline \multicolumn{9}{|c|}{ Внутрилинейный подбор } \\
\hline $\begin{array}{l}\text { Монтвик } \\
\text { Чифртейн }\end{array}$ & 64 & $346 \pm 15$ & $9487 \pm 631$ & $8270 \pm 612$ & $3,99 \pm 0,04$ & $330,00 \pm 13$ & $3,16 \pm 0,02$ & $261,3 \pm 12$ \\
\hline \begin{tabular}{|l|} 
Розейфр \\
Ситейшн
\end{tabular} & 58 & $330 \pm 14$ & $8835 \pm 617$ & $8180 \pm 594$ & $3,98 \pm 0,03$ & $325,60 \pm 17$ & $3,16 \pm 0,01$ & $258,49 \pm 13$ \\
\hline $\begin{array}{l}\text { Ресрлекшн } \\
\text { Соверинг }\end{array}$ & 64 & $326 \pm 16$ & $8685 \pm 627$ & $8185 \pm 582$ & $3,99 \pm 0,02$ & $326,58 \pm 10$ & $3,16 \pm 0,01$ & $258,65 \pm 11$ \\
\hline $\begin{array}{l}\text { Пабст } \\
\text { Говернера }\end{array}$ & 59 & $324 \pm 13$ & $8720 \pm 619$ & $8225 \pm 587$ & $3,99 \pm 0,03$ & $328,18 \pm 11$ & $3,16 \pm 0,02$ & $259,91 \pm 12$ \\
\hline $\begin{array}{l}\text { Силинг } \\
\text { Трайджун } \\
\text { Рокит }\end{array}$ & 45 & $352 \pm 17$ & $9465 \pm 712$ & $8174 \pm 604$ & $3,97 \pm 0,04$ & $324,51 \pm 15$ & $3,15 \pm 0,01$ & $257,48 \pm 14$ \\
\hline
\end{tabular}




\begin{tabular}{|l|c|c|c|c|c|c|c|c|}
\hline \multicolumn{1}{|c|}{ 1 } & 2 & 3 & 4 & 5 & 6 & 7 & 8 & 9 \\
\hline \multicolumn{7}{|c|}{ Кросс линии } \\
\hline М.Ч. $\times$ Р.Сов. & 155 & $340 \pm 15$ & $8518 \pm 614$ & $7674 \pm 553$ & $3,97 \pm 0,03$ & $304,65 \pm 12$ & $3,17 \pm 0,02$ & $243,27 \pm 13$ \\
\hline М.Ч.×Р.Сит. & 49 & $360 \pm 16$ & $8387 \pm 603$ & $6989 \pm 503$ & $3,99 \pm 0,02$ & $278,9 \pm 13$ & $3,16 \pm 0,01$ & $220,85 \pm 12$ \\
\hline М.Ч.×В.Б.А. & 43 & $403 \pm 18$ & $10544 \pm 838$ & $7988 \pm 635$ & $4,00 \pm 0,02$ & $319,5 \pm 15$ & $3,14 \pm 0,02$ & $250,82 \pm 14$ \\
\hline М.Ч.×С.Т.Р. & 57 & $378 \pm 17$ & $9713 \pm 701$ & $7837 \pm 566$ & $3,95 \pm 0,03$ & $309,6 \pm 14$ & $3,15 \pm 0,02$ & $246,87 \pm 13$ \\
\hline М.Ч.×П.Г. & 54 & $377 \pm 17$ & $10178 \pm 813$ & $8235 \pm 658$ & $4,00 \pm 0,02$ & $329,4 \pm 16$ & $3,18 \pm 0,01$ & $261,87 \pm 1$ \\
\hline Р.Сит.×В.Б.А. & 13 & $424 \pm 19$ & $9566 \pm 720$ & $7882 \pm 593$ & $3,94 \pm 0,03$ & $310,6 \pm 14$ & $3,13 \pm 0,01$ & $246,71 \pm 13$ \\
\hline Р.Сит.×П.Г. & 28 & $378 \pm 17$ & $9875 \pm 697$ & $7970 \pm 563$ & $3,97 \pm 0,02$ & $316,4 \pm 15$ & $3,14 \pm 0,02$ & $250,26 \pm 14$ \\
\hline Р.Сит.×М.Ч. & 11 & $335 \pm 15$ & $8530 \pm 618$ & $7766 \pm 564$ & $3,98 \pm 0,03$ & $309,1 \pm 14$ & $3,15 \pm 0,01$ & $244,63 \pm 13$ \\
\hline Р.Сит.×Р.Сов. & 72 & $399 \pm 17$ & $9588 \pm 718$ & $7430 \pm 556$ & $4,00 \pm 0,03$ & $297,2 \pm 12$ & $3,16 \pm 0,02$ & $234,79 \pm 12$ \\
\hline Р.Сит.×В.Б.А. & 8 & $452 \pm 21$ & $10549 \pm 872$ & $7518 \pm 621$ & $3,96 \pm 0,02$ & $297,7 \pm 12$ & $3,15 \pm 0,01$ & $236,82 \pm 12$ \\
\hline Р.Сов.×Р.Сит. & 16 & $318 \pm 14$ & $8780 \pm 783$ & $8418 \pm 751$ & $4,01 \pm 0,02$ & $331,6 \pm 16$ & $3,18 \pm 0,02$ & $261,69 \pm 15$ \\
\hline Р.Сов.×М.Ч. & 4 & $407 \pm 16$ & $10399 \pm 857$ & $7795 \pm 642$ & $3,93 \pm 0,01$ & $306,3 \pm 14$ & $3,16 \pm 0,02$ & $246,32 \pm 13$ \\
\hline Р.Сов.×С.Т.Р. & 2 & $305 \pm 10$ & $7428 \pm 598$ & $7428 \pm 598$ & $3,98 \pm 0,02$ & $295,6 \pm 12$ & $3,18 \pm 0,01$ & $236,22 \pm 12$ \\
\hline
\end{tabular}

Из анализа данных таблицы 1 следует, что при внутрипородном подборе наиболее высокие удои как за всю лактацию, так и за 305 дней были у первотелок линии Монтвик Чифтейн, которые превосходили удои первотелок линий Розейф Ситейшн на 90 кг (1,1%), Рефлекшн Соверинг - на 85 кг (1,0\%), Пабст Говернера на 45 кг (0,5 \%), Силинг Трайджун Рокит - на 96 кг $(1,2 \%)$. По количеству молочного жира и белка первотелки линии Монтвик Чифтейн также превосходили животных Розейф Ситейшн на 4,4 кг $(1,5 \%)$ и 2,8 кг (1,00 \%), а линии Рефрлекшн Соверинг - на 3,42 кг (1,05\%) и на 2,65 кг (1,02\%), Пабст Говернера - на 1,82 кг (0,55 \%) и 1,38 кг $(0,53 \%)$, Силинг Трайджун Рокит - на 5,49 кг $(1,69 \%)$ и 3,82 кг (1,98 \%) соответственно.

При сравнении продуктивности кроссированных первотелок по молочной продуктивности можно выделить сочетание линий Р. Сов. $\mathrm{x}$ Р. Сит. и М. Ч. х П. Г., которые между собой имеют небольшие различия, а в других сочетаниях превосходят показатели: по удою - на 3,1$20,5 \%$, выходу молочного жира - на 2,8419,3\%. По содержанию белка в молоке также, как при внутрилинейном подборе, достоверных различий между кроссами не установлено. В целом же, сравнивая показатели линии Монтвик Чифттейн при внутрипородном подборе и лучшие варианты кросса линий Р. Сов. × Р. Сит. и
М. Ч. × П. Г., можно отметить, что они имеют практически одинаковые показатели по удою, количеству молочного жира, массовой доли в молоке жира и белка.

Показатели молочной продуктивности первотелок енисейского типа красно-пестрой породы разных линий при внутрипородном подборе в зависимости от возраста первого отела представлены в таблице 2.

Наиболее высокий удой у первотелок наблюдался с возрастом 1-го отела в 21-22 месяца (1-я группа) во всех линиях, что, вероятно, обусловлено физиологической готовностью организма к лактации. При этом первотелки линии Монтвик Чифтейн 1-й группы превосходили по молочной продуктивности за 305 дней лактации первотелок 2-й, 3-й, и 4-й группы на 469 кг $(5,5 \%), 941(11,2 \%)$ и 1410 кг (18,6 \%) соответственно.

В линии Силинг Трайджун Рокит первотелки 1-й группы превосходили по удою первотелок 2-й, 3-й и 4-й групп на 500 кг (5,9\%), 1000 кг $(11,3 \%)$ и 2164 кг (31,8\%).

В линии Рефлекшн Соверинг преимущество 1-й группы первотелок по удою над первотелками 2-й, 3-й, и 4-й группами составило 510 кг (6,1 \%), 991 кг (12,5\%), 1475 кг (19,9\%) соответственно. 
Молочная продуктивность первотелок за 305 дней лактации, полученных внутрилинейным подбором

\begin{tabular}{|c|c|c|c|c|c|c|}
\hline \multirow{2}{*}{ Линия } & \multirow{2}{*}{ Показатель } & \multicolumn{5}{|c|}{$\begin{array}{c}\text { Группа первотелок с отелами } \\
\text { (в месяцах от рождения) }\end{array}$} \\
\hline & & $\begin{array}{c}1 \\
(21-22)\end{array}$ & $\begin{array}{c}2 \\
(23-24)\end{array}$ & $\begin{array}{c}3 \\
(25-26) \\
\end{array}$ & $\begin{array}{c}4 \\
(27-28) \\
\end{array}$ & $\begin{array}{c}5 \\
(21-28) \\
\end{array}$ \\
\hline \multirow{5}{*}{$\begin{array}{l}\text { Монтвик } \\
\text { Чифртейн }\end{array}$} & Голов & 16 & 16 & 17 & 15 & 64 \\
\hline & удой, кг & $8975 \pm 664$ & $8506 \pm 629$ & $8034 \pm 595$ & $7565 \pm 560$ & $8270 \pm 612$ \\
\hline & МДЖ, \% & $4,01 \pm 0,04$ & $4,01 \pm 0,04$ & $3,97 \pm 0,03$ & $3,95 \pm 0,05$ & $3,99 \pm 0,04$ \\
\hline & МДБ, \% & $3,16 \pm 0,01$ & $3,16 \pm 0,03$ & $3,13 \pm 0,02$ & $3,20 \pm 0,02$ & $3,16 \pm 0,02$ \\
\hline & Живая масса, кг & $520 \pm 36$ & $525 \pm 37$ & $527 \pm 38$ & $532 \pm 38$ & $526 \pm 38$ \\
\hline \multirow{5}{*}{$\begin{array}{l}\text { Розейф } \\
\text { Ситейшн }\end{array}$} & Голов & 14 & 15 & 15 & 14 & 58 \\
\hline & Удой, кг & $8915 \pm 647$ & $8456 \pm 614$ & $7921 \pm 575$ & $7428 \pm 540$ & $8180 \pm 594$ \\
\hline & МДЖ, \% & $3,98 \pm 0,04$ & $4,01 \pm 0,02$ & $3,96 \pm 0,04$ & $3,96 \pm 0,02$ & $3,98 \pm 0,03$ \\
\hline & МДБ, \% & $3,14 \pm 0,01$ & $3,15 \pm 0,01$ & $3,14 \pm 0,01$ & $3,19 \pm 0,01$ & $3,16 \pm 0,01$ \\
\hline & Живая масса, кг & $519 \pm 36$ & $524 \pm 35$ & $526 \pm 37$ & $530 \pm 39$ & $525 \pm 35$ \\
\hline \multirow{5}{*}{$\begin{array}{l}\text { Рефрлекшн } \\
\text { Соверинг }\end{array}$} & Голов & 16 & 17 & 16 & 15 & 64 \\
\hline & Удой, кг & $8929 \pm 684$ & $8419 \pm 645$ & $7938 \pm 608$ & $7454 \pm 571$ & $8185 \pm 627$ \\
\hline & МДЖ, \% & $4,03 \pm 0,03$ & $3,99 \pm 0,01$ & $3,98 \pm 0,03$ & $3,97 \pm 0,01$ & $3,99 \pm 0,02$ \\
\hline & МДБ, \% & $3,14 \pm 0,01$ & $3,16 \pm 0,01$ & $3,15 \pm 0,01$ & $3,18 \pm 0,02$ & $3,16 \pm 0,01$ \\
\hline & Живая масса, кг & $519 \pm 36$ & $521 \pm 37$ & $527 \pm 38$ & $529 \pm 38$ & $524 \pm 37$ \\
\hline \multirow{5}{*}{$\begin{array}{l}\text { Пабст } \\
\text { Говернер }\end{array}$} & Голов & 14 & 15 & 16 & 14 & 59 \\
\hline & Удой, кг & $8916 \pm 637$ & $8423 \pm 601$ & $8024 \pm 573$ & $7537 \pm 538$ & $8225 \pm 587$ \\
\hline & МДЖ, \% & $4,01 \pm 0,04$ & $4,00 \pm 0,01$ & $3,98 \pm 0,02$ & $3,97 \pm 0,04$ & $3,99 \pm 0,03$ \\
\hline & МДБ, \% & $3,15 \pm 0,02$ & $3,15 \pm 0,01$ & $3,14 \pm 0,03$ & $3,18 \pm 0,01$ & $3,16 \pm 0,02$ \\
\hline & Живая масса, кг & $515 \pm 37$ & $520 \pm 37$ & $526 \pm 38$ & $531 \pm 38$ & $523 \pm 37$ \\
\hline \multirow{5}{*}{$\begin{array}{l}\text { Силинг } \\
\text { Трайджун } \\
\text { Рокит }\end{array}$} & Голов & 12 & 11 & 10 & 12 & 45 \\
\hline & Удой, кг & $8965 \pm 662$ & $8465 \pm 626$ & $7965 \pm 589$ & $6801 \pm 503$ & $8174 \pm 604$ \\
\hline & МДЖ, \% & $3,99 \pm 0,02$ & $3,98 \pm 0,01$ & $3,96 \pm 0,03$ & $3,95 \pm 0,02$ & $3,97 \pm 0,02$ \\
\hline & МДБ, \% & $3,14 \pm 0,01$ & $3,14 \pm 0,01$ & $3,13 \pm 0,01$ & $3,17 \pm 0,01$ & $3,15 \pm 0,01$ \\
\hline & Живая масса, кг & $514 \pm 36$ & $519 \pm 36$ & $525 \pm 37$ & $530 \pm 38$ & $522 \pm 37$ \\
\hline
\end{tabular}

В линии Пабст Говернер преимущество 1-й группы первотелок по удою над первотелками 2-й, 3-й, и 4-й группами составило 493 кг (5,8 \%), 892 кг (11,1\%) и 1379 кг (18,3\%) соответственно.

В линии Розейф Ситейшн преимущество 1-й группы первотелок по удою над первотелками 2-й, 3-й, и 4-й группами составило 459 кг (5,4%), 994 кг (12,5 \%) и 1487 кг (20,0 \%).
По содержанию жира и белка в молоке у первотелок с отелами 21 месяц и по 28-й достоверных различий внутри линий и между ними по группам не установлено.

В таблице 3 приведены показатели молочной продуктивности первотелок в зависимости от возраста отела, полученных путем кросса линией. 


\section{Молочная продуктивность первотелок в зависимости от возраста отела, полученных путем кросса линий}

\begin{tabular}{|c|c|c|c|c|c|}
\hline \multirow{2}{*}{ Линия } & \multirow{2}{*}{ Показатель } & \multicolumn{4}{|c|}{$\begin{array}{c}\text { Группа первотелок с отелами } \\
\text { в месяцах от рождения }\end{array}$} \\
\hline & & $\begin{array}{c}1 \\
(21-22)\end{array}$ & $\begin{array}{c}2 \\
(23-24)\end{array}$ & $\begin{array}{c}3 \\
(25-26)\end{array}$ & $\begin{array}{c}4 \\
(27-28)\end{array}$ \\
\hline 1 & 2 & 3 & 4 & 5 & 6 \\
\hline \multirow{5}{*}{ М.Ч.×Р.Сов. } & Голов & 63 & 68 & 19 & 5 \\
\hline & Кол-во дойных дней & 346 & 316 & 338 & 377 \\
\hline & Удой за 305 дней, кг & $8121 \pm 738$ & $7948 \pm 722$ & $7986 \pm 726$ & $7273 \pm 661$ \\
\hline & МДЖ, \% & $3,97 \pm 0,02$ & $3,98 \pm 0,04$ & $3,97 \pm 0,02$ & $3,99 \pm 0,03$ \\
\hline & МДБ, \% & $3,16 \pm 0,03$ & $3,16 \pm 0,01$ & $3,17 \pm 0,02$ & $3,18 \pm 0,02$ \\
\hline \multirow{5}{*}{ М.Ч.×Р.Сит. } & Голов & 17 & 25 & 13 & 4 \\
\hline & Кол-во дойных дней & 369 & 382 & 348 & 355 \\
\hline & Удой за 305 дней, кг & $7727 \pm 536$ & $7360 \pm 563$ & $7286 \pm 541$ & $7089 \pm 524$ \\
\hline & МДЖ, \% & $4,03 \pm 0,04$ & $4,00 \pm 0,02$ & $3,97 \pm 0,03$ & $3,95 \pm 0,03$ \\
\hline & МДБ, \% & $3,17 \pm 0,01$ & $3,14 \pm 0,01$ & $315 \pm 0,01$ & $3,16 \pm 0,01$ \\
\hline \multirow{5}{*}{ М.Ч.×В.Б.А. } & Голов & 2 & 2 & 2 & 2 \\
\hline & Кол-во дойных дней & 351 & 403 & 372 & 368 \\
\hline & Удой за 305 дней, кг & $8409 \pm 631$ & $8280 \pm 621$ & $8085 \pm 606$ & $7825 \pm 587$ \\
\hline & МДЖ, \% & $3,98 \pm \pm 0,01$ & $4,01 \pm \pm 0,03$ & $3,96 \pm \pm 0,01$ & $3,97 \pm \pm 0,02$ \\
\hline & МДБ, \% & $3,15 \pm 0,02$ & $3,14 \pm 0,03$ & $3,13 \pm 0,01$ & $3,14 \pm 0,02$ \\
\hline \multirow{5}{*}{ M.Ч.×C.Т.P. } & Голов & 19 & 12 & 15 & 11 \\
\hline & Кол-во дойных дней & 440 & 366 & 360 & 361 \\
\hline & Удой за 305 дней, кг & $8842 \pm 682$ & $7990 \pm 585$ & $7489 \pm 589$ & $7195 \pm 519$ \\
\hline & МДЖ, \% & $3,94 \pm 0,03$ & $3,95 \pm 0,01$ & $3,95 \pm 0,02$ & $3,98 \pm 0,03$ \\
\hline & МДБ, \% & $3,15 \pm 0,03$ & $3,14 \pm 0,01$ & $3,15 \pm 0,02$ & $3,14 \pm 0,02$ \\
\hline \multirow{5}{*}{ М.Ч.×П.Г. } & Голов & 8 & 15 & 2 & 2 \\
\hline & Кол-во дойных дней & 391 & 318 & 422 & 437 \\
\hline & Удой за 305 дней, кг & $8256 \pm 726$ & $7814 \pm 687$ & $7628 \pm 672$ & $7482 \pm 658$ \\
\hline & МДЖ, \% & $4,03 \pm 0,02$ & $394 \pm 0,01$ & $3,97 \pm 0,03$ & $3,97 \pm 0,02$ \\
\hline & МДБ, \% & $3,15 \pm 0,04$ & $3,13 \pm 0,02$ & $3,15 \pm 0,03$ & $3,15 \pm 0,02$ \\
\hline \multirow{5}{*}{ Р.Сит.×В.Б.А. } & Голов & 5 & - & 4 & 4 \\
\hline & Кол-во дойных дней & 329 & - & 500 & 424 \\
\hline & Удой за 305 дней, кг & $8269 \pm 692$ & - & $7392 \pm 554$ & $7029 \pm 478$ \\
\hline & МДЖ, \% & $3,91 \pm 0,03$ & - & $3,98 \pm 0,03$ & $3,93 \pm \pm 0,03$ \\
\hline & МДБ, \% & $3,15 \pm 0,01$ & - & $3,14 \pm 0,02$ & $3,13 \pm 0,01$ \\
\hline \multirow{5}{*}{ Р.Сит.хП.Г. } & Голов & 2 & 4 & 20 & 2 \\
\hline & Кол-во дойных дней & 297 & 371 & 390 & 435 \\
\hline & Удой за 305 дней, кг & $8658 \pm 814$ & $8118 \pm 763$ & $7410 \pm 697$ & $7020 \pm 661$ \\
\hline & МДЖ, \% & $3,95 \pm 0,02$ & $4,00 \pm 0,04$ & $3,96 \pm 0,03$ & $3,95 \pm 0,03$ \\
\hline & МДБ, \% & $3,12 \pm 0,02$ & $3,15 \pm 0,02$ & $3,13 \pm 0,01$ & $3,13 \pm 0,02$ \\
\hline
\end{tabular}


Вестник КрасТАУ. 2019. № 11

Окончание табл. 3

\begin{tabular}{|c|c|c|c|c|c|}
\hline 1 & 2 & 3 & 4 & 5 & 6 \\
\hline \multirow{5}{*}{ Р.Сит.×М.Ч. } & Голов & 6 & 5 & - & - \\
\hline & Кол-во дойных дней & 335 & 327 & - & - \\
\hline & Удой за 305 дней, кг & $8330 \pm 593$ & $8028 \pm 658$ & - & - \\
\hline & МДЖ, \% & $3,98 \pm 0,03$ & $3,98 \pm 0,03$ & - & - \\
\hline & МДБ, \% & $3,15 \pm 0,01$ & $3,15 \pm 0,04$ & - & - \\
\hline \multirow{5}{*}{ Р.Сит.хР.Сов. } & Голов & 16 & 23 & 9 & 24 \\
\hline & Кол-во дойных дней & 394 & 458 & 348 & 394 \\
\hline & Удой за 305 дней, кг & $8116 \pm 638$ & $7522 \pm 571$ & $7291 \pm 573$ & $7085 \pm 709$ \\
\hline & МДЖ, \% & $4,34 \pm 0,04$ & $3,96 \pm 0,03$ & $3,96 \pm 0,03$ & $4,03 \pm 0,02$ \\
\hline & МДБ, \% & $3,16 \pm 0,02$ & $3,14 \pm 0,01$ & $3,14 \pm 0,04$ & $3,14 \pm 0,02$ \\
\hline \multirow{5}{*}{ Р.Сит.×В.Б.А. } & Голов & 2 & 2 & 2 & 2 \\
\hline & Кол-во дойных дней & 321 & 546 & 500 & 442 \\
\hline & Удой за 305 дней, кг & $7899 \pm 578$ & $7517 \pm 561$ & $6768 \pm 495$ & $6435 \pm 709$ \\
\hline & МДЖ, \% & $3,99 \pm 0,02$ & $3,95 \pm 0,03$ & $3,98 \pm 0,02$ & $3,93 \pm 0,02$ \\
\hline & МДБ, \% & $3,19 \pm 0,01$ & $3,15 \pm 0,01$ & $3,11 \pm 0,01$ & $3,14 \pm 0,02$ \\
\hline \multirow{5}{*}{ Р.Сов.×Р.Сит. } & Голов & 4 & 4 & 4 & 4 \\
\hline & Кол-во дойных дней & 312 & 297 & 363 & 305 \\
\hline & Удой за 305 дней, кг & $8744 \pm 721$ & $8533 \pm 667$ & $7987 \pm 586$ & $7103 \pm 520$ \\
\hline & МДЖ, \% & $3,96 \pm 0,01$ & $3,93 \pm 0,02$ & $4,00 \pm 0,02$ & $3,95 \pm 0,03$ \\
\hline & МДБ, $\%$ & $3,17 \pm 0,01$ & $3,15 \pm 0,03$ & $3,18 \pm 0,01$ & $3,18 \pm 0,02$ \\
\hline \multirow{5}{*}{ Р.Сов. ×М.Ч. } & Голов & 2 & 2 & - & - \\
\hline & Кол-во дойных дней & 409 & 404 & - & - \\
\hline & Удой за 305 дней, кг & $7803 \pm 581$ & $7834 \pm 574$ & - & - \\
\hline & МДЖ, \% & $3,97 \pm 0,04$ & $3,97 \pm 0,04$ & - & - \\
\hline & МДБ, \% & $3,16 \pm 0,02$ & $3,16 \pm 0,02$ & - & - \\
\hline \multirow{5}{*}{ P.Сов. $\times$ C.T.P. } & Голов & 2 & - & - & - \\
\hline & Кол-во дойных дней & 305 & - & - & - \\
\hline & Удой за 305 дней, кг & $7921 \pm 581$ & - & - & - \\
\hline & МДЖ, \% & $3,98 \pm 0,02$ & - & - & - \\
\hline & МДБ, \% & $3,18 \pm 0,01$ & - & - & - \\
\hline
\end{tabular}

Среди кроссированных первотелок, также как и у полученных внутрилинейным подбором, наблюдается тенденция снижения количества получаемого молока при возрасте первого отела свыше 21-22 месяца, при этом превосходство по удою в 1-й группе в сравнении со 2-й, 3-й, и 4-й группами наблюдалось в кроссе М.Ч. × С.Т.Р. на 852 кг $(10,7 \%), 1356$ кг (18,1\%) и 1647 кг (22,9 \%). Следовательно, межлинейный подбор быков линии С.Т.Р. к телкам и коровам линии М.Ч. в сочетании с возрастом первого отела в 21 и 22 месяца дает лучшее проявление молочной продуктивности в 1-й группе в сравнении со 2-й, 3-й, 4-й группами на 852 кг (10,7 \%), 1353 кг (18,1\%), 1647 кг (22,9 \%) соответственно; по выходу молочного жира на 19,6 (6,4 \%)-29,25 кг (10,6\%), по выходу молочного белка - на 32,8 (10,4 \%)-62,0 кг (21,66 \%).

\section{Выводы}

1. При внутрипородном подборе животных енисейского типа красно-пестрой породы из 5 используемых линий (М.Ч., Р. Сит., Р. Сов., П.Г., С.Т.Р.) у первотелок линии М.Ч. в сравнении с другими линиями обусловлено лучшей наследственностью проявление признаков молочной продуктивности (по удою +0,53-1,5 \%, по выходу молочного жира и белка +0,53-1,5\% и + 0,61,7\% соответственно).

2. При внутрилинейном подборе первотелки линии М.Ч. в сравнении с другими линиями проявили лучшие возможности не только наследственно передавать потомкам признаки молочной продуктивности, но и лучше использовать биологические способности в достижении опти- 
мальных показателей в росте и развитии в молодом возрасте (случка в 12-13 месяцев, с живой массой 382 кг, отел в 21-22 месяца с живой массой 514 кг), что способствовало увеличению за 305 дней лактации удоя на 0,6-1,2 \%, выходу молочного жира и белка - на 0,6-1,7 \% и 0,51,5\% соответственно.

3. Наследственные и биологические способности лучше проявились у первотелок при межлинейном подборе линий М.Ч. × С.Т.Р., которые в сравнении с другими кроссированными первотелками дали увеличение удоя на 10,7-22,9 \%, по выходу молочного жира и белка - на 6,410,6 \% и на 10,4-21,7 \% соответственно.

Продуктивность коров за 305 дней лактации (удой, выход молочного жира и белка) в племзаводе можно увеличить на 0,5-1,7 \% при интенсивном использовании в селекции животных линии Монтвик Чифтейн, полученных от внутрилинейного разведения, и на 6,4-21,7 \% - от кросса линий Монтвик Чифттейн $\times$ Силинг Трайджун Рокит, полученных методом линейного подбора и слученных в возрасте 12-13 месяцев, с живой массой 384 кг, у которых в сравнении с другими линиями и кроссами наследственно обусловлена лучшая способность передавать признаки молочной продуктивности потомкам.

\section{Литература}

1. Дунин И.М., Бальцанов А.И., Рьжова Н.Г. Красно-пестрая порода молочного скота России. - М.: Изд-во ВНИИплем, 2010. $199 \mathrm{c}$.

2. Голубков А.И., Лущенко А.Е., Шадрин С.В. и др. Разведение и использование чернопестрой и красно-пестрой молочных пород в Красноярском крае. - Красноярск, 2005. $240 \mathrm{c}$.
3. Дунин И.М., Лозовая Г.С., Чекушкин А.М. Генетический потенциал племенных ресурсов стад красно-пестрой породы молочного скота // Молочное и мясное скотоводство. 2015. - № 8. - С. 3-6.

4. Амерханов Х.А., Стрекозов Н.И. Научное обоснование конкуренто-способности молочного скотоводства // Молочное и мясное производство: спецвыпуск по молочному скотоводству. - 2012. - № 1. - С. 2-6.

5. Дунин И.М., Амерханов Х.А. Селекционнотехнологические аспекты развития молочного скотоводства в России // Зоотехния. 2017. - № 6. - С. 2-8.

\section{Literatura}

1. Dunin I.M., Bal'canov A.I., Ryzhova N.G. Krasno-pestraya poroda molochnogo skota Rossii. - M.: Izd-vo VNIIplem, 2010. - 199 s.

2. Golubkov A.I., Lushchenko A.E., SHadrin S.V. i dr. Razvedenie i ispol'zovanie cherno-pestroj i krasno-pestroj molochnyh porod $\mathrm{V}$ Krasnoyarskom krae. - Krasnoyarsk, 2005. $240 \mathrm{~s}$.

3. Dunin I.M., Lozovaya G.S., CHekushkin A.M. Geneticheskij potencial plemennyh resursov stad krasno-pestroj porody molochnogo skota // Molochnoe i myasnoe skotovodstvo. 2015. - № 8. - S. 3-6.

4. Amerhanov H.A., Strekozov N.I. Nauchnoe obosnovanie konkurento-sposobnosti molochnogo skotovodstva // Molochnoe i myasnoe proizvodstvo: specvypusk po molochnomu skotovodstvu. - 2012. - № 1. - S. 2-6.

5. Dunin I.M., Amerhanov H.A. Selekcionnotekhnologicheskie aspekty razvitiya molochnogo skotovodstva v Rossii // Zootekhniya. 2017. - № 6. - S. 2-8. 